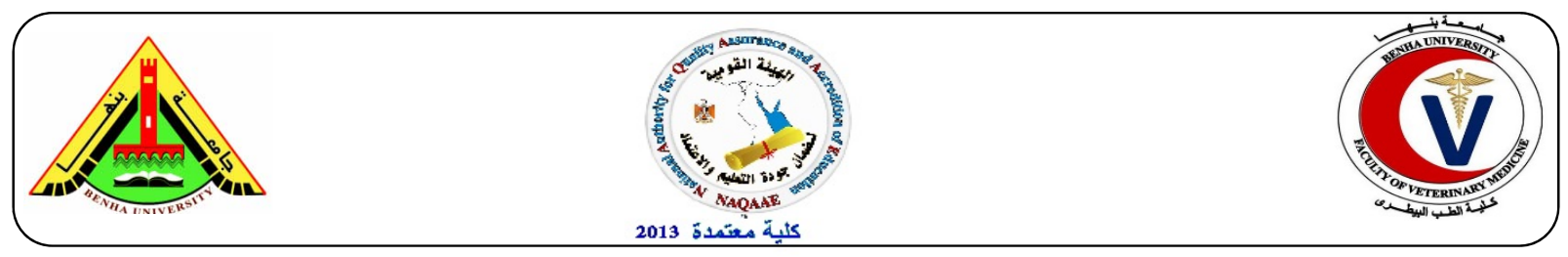

\title{
Aflatoxins residues in chicken and turkey tissues
}

\author{
Faten, S. Hasanen ${ }^{a}$, Mousa, M. Mohammed ${ }^{b}$, Mahomud, A. H.c, Wafaa, M. Hassand and Fatma, \\ H. Amro

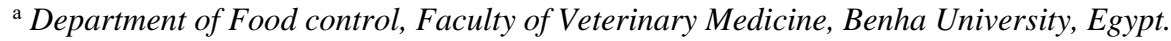 \\ ${ }^{B}$ Department of Food control, Faculty of Veterinary Medicine, Adfina University, Egypt. \\ ${ }^{c}$ Department of Biotechnology, Animal Health Research Institute, Dokki, Gizza. \\ ${ }^{d}$ Reference Laboratory for Veterinary Quality Control on Poultry Production, Animal Health Research Institute, Dokki,
}

\section{A B S T R A C T}

Total aflatoxins residues were detected in chicken and turkey tissues "muscles and liver " by using HPLC. Results revealed a significant difference variation among liver and muscles in examined chicken and turkey's samples ( $p$ values $<0.05$ ). These indicated that liver is the reservoir place of total aflatoxins residues. The means average of Aflatoxin B1, G1, B2, $\mathrm{G} 2$ and total aflatoxins residues respectively, in examined chicken liver samples were $17.3+/-3.3 \mu \mathrm{g} / \mathrm{kg}, 13.5+/-2.1 \mu \mathrm{g} / \mathrm{kg}$, $7.6+/-4.8 \mu \mathrm{g} / \mathrm{kg}, 1.5+/-0.9 \mu \mathrm{g} / \mathrm{kg}$ and $22.8+/-4.1 \mu \mathrm{g} / \mathrm{kg}$. while in examined muscles samples they were $6.5+/-1.03 \mu \mathrm{g} / \mathrm{kg}$, $4+/-1.4 \mu \mathrm{g} / \mathrm{kg}, 1.7+/-0.6 \mu \mathrm{g} / \mathrm{kg}, 0.7+/-0.3 \mu \mathrm{g} / \mathrm{kg}$ and $8.9+/-1.5 \mu \mathrm{g} / \mathrm{kg}$. On the other side the means for Aflatoxin B1, G1, $\mathrm{B} 2, \mathrm{G} 2$ and total aflatoxins residues respectively, in examined turkey liver samples they were $15.6+/-2.7 \mu \mathrm{g} / \mathrm{kg}, 13+/-$ $4.2 \mu \mathrm{g} / \mathrm{kg}, 6.1+/-0.5 \mu \mathrm{g} / \mathrm{kg}, 2.2+/-0.6 \mu \mathrm{g} / \mathrm{kg}$ and $24.5+/-4.7 \mu \mathrm{g} / \mathrm{kg}$, while in turkey muscles samples were $6.3+/-1.5 \mu \mathrm{g} / \mathrm{kg}$, $4+/-0.2 \mu \mathrm{g} / \mathrm{kg}, 2.9+/-1.3 \mu \mathrm{g} / \mathrm{kg}, 0.6+/-0.3 \mu \mathrm{g} / \mathrm{kg}$ and $9.3+/-2.5 \mu \mathrm{g} / \mathrm{kg}$.

Key Words: Residues -Aflatoxins -Chicken- Turkeys -HPLC.

(http://www.bvmj.bu.edu.eg)

(BVMJ-31(2): 130-135, 2016)

\section{INTRODUCTION}

Mycotoxins are natural secondary toxic metabolite products of mould fungi, that contaminate our foodstuff. Dance et al. (2003), Aflatoxins are major toxic carcinogenic substances produced by Aspergillus flavus, A. parasiticus. Generally, aflatoxin B1, G1, B2, and G2 are common types of aflatoxins (Kalcher et al., 2007). Less qualified and less hygienic handling of carcasses on preparation after slaughtering beside improper evisceration, that in role lead to highly bacterial count. In addition to bad chilling proliferate mould contamination so food spoilage occur that enhance toxins production as aflatoxins (Lacumin et al., 2009; Martín-Sánchez et al., 2011). Aflatoxins naming according to blue (B) or green $(G)$ fluorescence emitted under ultraviolet light and their migration properties within chromatography (Diekman and Green, 1992). Liver is the harbor site for the accumulation of aflatoxins residues than other tissues in frozen chicken recorded by (Darwish et al., 2016). Accumulation of aflatoxins residues in human in acute cases is lethal due to intoxication, in chronic cases leads to hepatocellular carcinoma (Bennett and Klich, 2003; Miliţă et al., 2010). Aflatoxins were classified by the International Agency for Research on Cancer and belonged to group 1 that included substances which are carcinogenic for humans according to IARC (1993) and Talebi et al. (2011) who pronounced that aflatoxin B1 is the extremely toxic type and belonging to the main group of carcinogenicity in human.

\section{MATERIAL AND METHODS}

Total aflatoxins standards were obtained from Sigma (St. Louis, MO, USA) of $99 \%$ purity. Preparing of working solution were in acetonitrile and stored at $-20{ }^{\circ} \mathrm{C}$ in amber glass vials over a period of 12 months.

\subsection{Field survey tissue sampling plane}

A grand total of 60 chicken and turkey tissue samples "30 of each". The samples represented as 15 samples of each tissues "muscles and liver". The samples were collected from special abattoir in Qalyiobyam and Giza Governorate as fresh samples. Each sample was represented by 20 grams. The samples were placed in plastic bags 
then transferred to the laboratory without undue delay in an ice box.

\subsection{Apparatus and Equipment}

Liquid chromatography: - (HPLC)Agilent Series 1200. Analytical column (stationary phase) C18. Solid-phase extraction (SPE) columns: -Bond Elut C18.HLB Oasis cartridges $(6 \mathrm{ml})$ Electronic digital balance, Moulinette, mincer, Shaker, nitrogen evaporator, vacuum manifold and acrodiscs $(0.45 \mu \mathrm{m})$.

\subsection{Chemical reagents}

Deionized water (HPLC-grade). Acetonitrile, Methanol "HPLC grade" were obtained from Sigma Alderish and Acetic acid diluted in water. $20 \%$ citric acid from Merck (Darmstadt, Germany), dichloromethane, nitrogen evaporator, Hexane, petroleum ether, acetone, and trifloroacetic acid were obtained from Fischer scientific (Leicestershire, UK).

\subsection{Analytical Procedures}

\subsubsection{Preparation of samples for analysis}

The chicken and turkey samples were homogenized and frozen till the time of analysis at $-20^{\circ} \mathrm{c}$ in the dark.

\subsubsection{Extraction of aflatoxins}

Extraction of total aflatoxins_residues from Chicken and turkey tissues was done according to Abd El Monem et al. (2015). SPE (Solid Phase Extraction) and derivatization step done according to Kalantari et al. (1999). twenty $\mu 1$ were injected into HPLC (Anklam et al., 2002).

\subsubsection{Liquid chromatographic conditions}

Injection volume, $20 \mu \mathrm{l}$, flow rate of 1.0 $\mathrm{mL} / \mathrm{min}$ to achieve the optimum resolution of the aflatoxins. The column temperature was at $30{ }^{\circ} \mathrm{C}$, fluorescence detector.

Liquid Chromatographic mobile phase: Isocratic mode using 60:20:20 water/methanol/acetonitrile mixture as the mobile phase according to Abd El Monem et al. (2015).

\subsection{Statistical Analysis}

The obtained results were statistically evaluated by using $t$ test according to Feldman et al. (2003).

\section{RESULTS}

The achieved results in table (1) declared the average mean of total aflatoxins residues in chicken samples, the average mean of aflatoxin B1 in examined chicken muscles and liver samples were higher than other types. The average means among chicken muscles and liver samples showed highly significant variation, as the residues in liver were higher than in muscles. The results in table (2) revealed that the average means of total aflatoxins residues in turkey samples. The mean of aflatoxin B1 was the highest in both turkey muscles and liver samples. Whereas the residual levels of total aflatoxins in liver were higher than that in muscle.

\section{DISCUSSION}

Due to the toxicological and carcinogenic impact of aflatoxins residues on human health and shortage on studies of aflatoxin residues in turkeys our study includes detecting the residues on aflatoxins types "B1, B2, G1, G 2 and total aflatoxins residues" in chicken and turkeys.

Table (1) Statistical analytical results of total aflatoxins residues $\mu \mathrm{g} / \mathrm{kg}$ in examined chicken tissues ( $\mathrm{n}=15)$.

\begin{tabular}{lcccccccccc}
\hline $\begin{array}{l}\text { Aflatoxins } \\
\text { residues }\end{array}$ & \multicolumn{3}{c}{ Muscles positive Samples } & & \multicolumn{5}{c}{ Liver } & positive samples \\
& No & M & Min. & Max. & Mean+/-SE & No & $\%$ & Min. & Max. & Mean+/-SE \\
\hline flatoxin B1 & 6 & 40 & 3.06 & 9.3 & $6.5+/-1.03$ & 6 & 40 & 7.8 & 30.6 & $17.3+/-3.3$ \\
Aflatoxin G1 & 4 & 26.7 & 2.2 & 8.1 & $4+/-1.4$ & 5 & 33.3 & 8.7 & 19.8 & $13.5+/-2.1$ \\
Aflatoxin B2 & 3 & 20 & 1 & 2.9 & $1.7+/-0.6$ & 4 & 26.7 & 2.2 & 22 & $7.6+/-4.8$ \\
Aflatoxin G2 & 3 & 20 & 0.12 & 1.01 & $0.7+/-0.3$ & 3 & 20 & 0.1 & 4.2 & $0.91 .4-/+$ \\
Total Aflatoxins & 7 & 46.7 & 3.06 & 14.51 & $8.9+/-1.5$ & 9 & 60 & 7.8 & 63.6 & $22.8+/-4.1$ \\
\hline
\end{tabular}

$\mathrm{S} . \mathrm{E}=$ Standard error of mean significant differences as $p<0.05$ using t test 
Table (2): Statistical analytical results of total aflatoxins residues in examined Turkey samples $(\mathrm{n}=15)$

\begin{tabular}{|c|c|c|c|c|c|c|c|c|c|c|}
\hline \multirow{3}{*}{$\begin{array}{l}\text { Aflatoxins } \\
\text { residues }\end{array}$} & \multirow{2}{*}{\multicolumn{2}{|c|}{$\begin{array}{l}\text { Muscles } \\
\text { Samples }\end{array}$}} & \multicolumn{3}{|c|}{ positive } & \multicolumn{3}{|c|}{ Liver } & \multicolumn{2}{|c|}{ positive } \\
\hline & & & \multirow[t]{2}{*}{ Min. } & \multirow[t]{2}{*}{ Max. } & \multirow[b]{2}{*}{ Mean +/-SE } & \multicolumn{2}{|c|}{ Samples } & \multirow[t]{2}{*}{ Min. } & \multirow[t]{2}{*}{ Max. } & \multirow[t]{2}{*}{ Mean+/-SE } \\
\hline & No & $\%$ & & & & No. & $\%$ & & & \\
\hline Aflatoxin B1 & 5 & 33.3 & 2.01 & 9.66 & $6.3+/-1.5$ & 6 & 40 & 8.12 & 26 & $15.6+/-2.7$ \\
\hline Aflatoxin G1 & 3 & 20 & 3.63 & 4.45 & $4+/-0.2$ & 4 & 26.7 & 3 & 23.1 & $13+/-4.2$ \\
\hline Aflatoxin B2 & 4 & 26.7 & 1.4 & 6.62 & $2.9+/-1.3$ & 3 & 20 & 5.4 & 7 & $6.1+/-0.5$ \\
\hline $\begin{array}{l}\text { Aflatoxin G2 } \\
\text { Total }\end{array}$ & 3 & 20 & 0.2 & 1.1 & $0.6+/-0.3$ & 3 & 20 & 1.18 & 3.3 & $2.2-/+0.6$ \\
\hline Aflatoxins & 6 & 40 & 2 & 16.97 & $9.3+/-2.5$ & 7 & 46.7 & 8.12 & 41.9 & $24.5+/-4.7$ \\
\hline
\end{tabular}

$\mathrm{SE}=$ Standard Error of mean Significant differences as $p$ value $<0.05$ by using $\mathrm{t}$ test.

Figure (1): calibration curve of total Aflatoxins residues by HPLC.

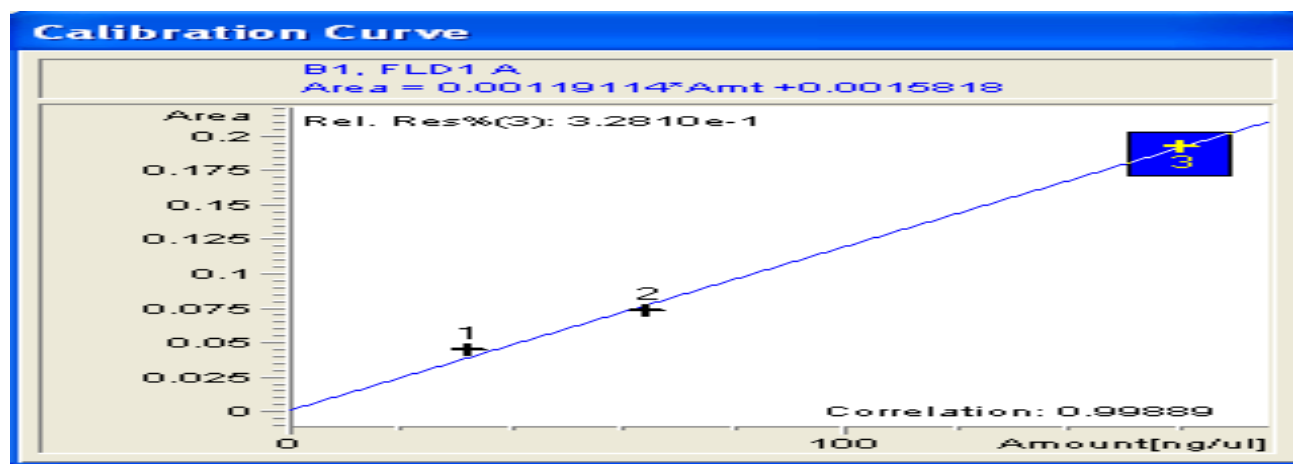

Figure (2): chromatograms of total aflatoxins standards $1375 \mu \mathrm{g} / \mathrm{kg}$.

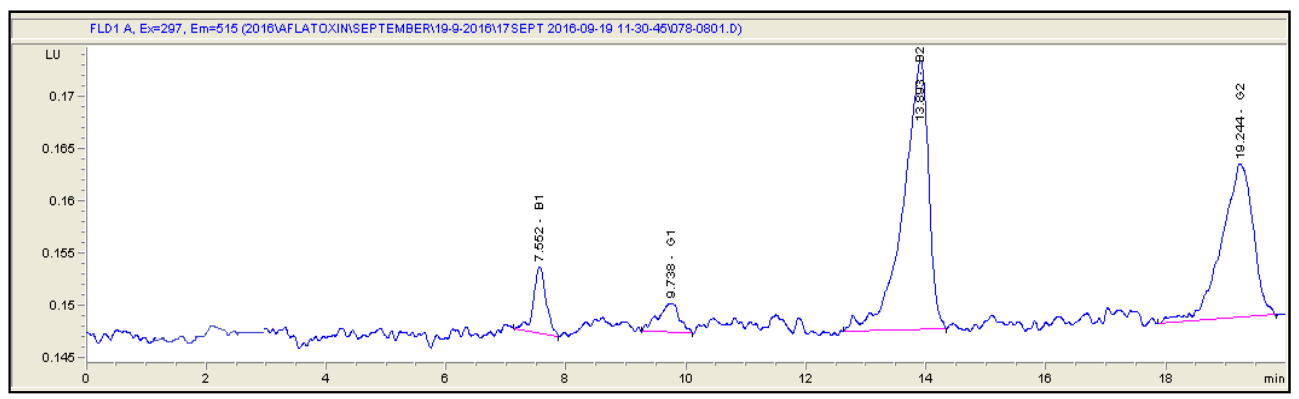

Figure (3): chromatograms of total aflatoxins residues in chicken (3) liver, (4) turkey liver samples.

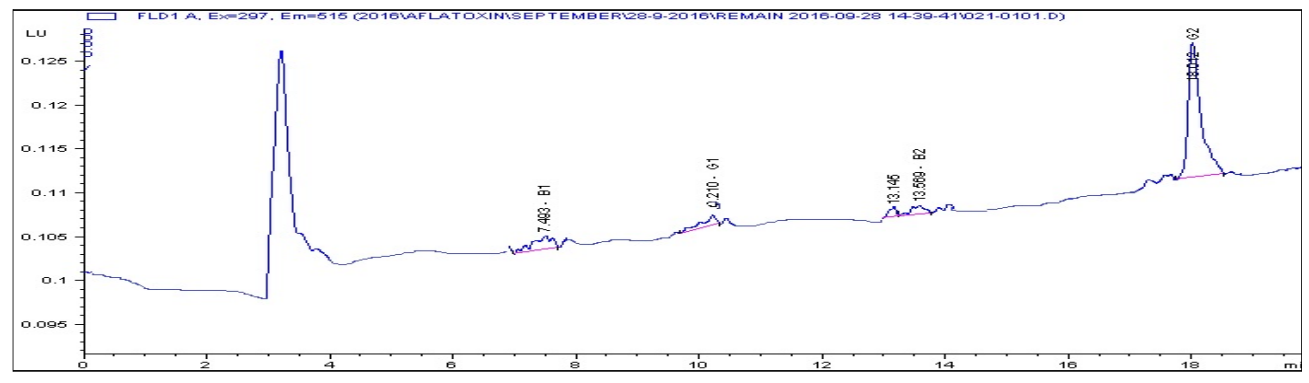


Figure (4): chromatograms of total aflatoxins residues in turkey liver samples.

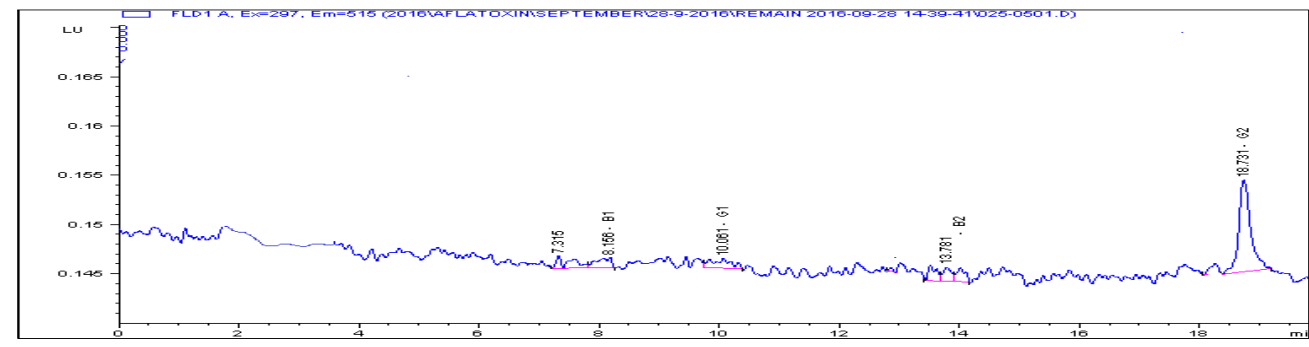

The current results in table (1) were agreed with those achieved by Resanović (2000) and Saeed et al. (2003) who declared that however aflatoxins residues found in liver, muscles, stomach, kidneys, adipose tissue and meat but liver is the harbor site of aflatoxin residues. In the same line the results agreed with those obtained by Herzallah (2013) and Darwish et al. (2016) who reported that the highest concentration of AFB1 and total aflatoxins were in liver higher than in kidneys than in gizzard, while the lowest concentrations were in thigh and breast. AFB1 is the extremely potent carcinogenic type of aflatoxins that responsible for carcinogenicity that grouped a human carcinogen by world health organization (Anklam et al., 2002).

The present results are completely disagreed with those achieved by Abo El-Yazeed et al. (2015) who detected that the residual concentrations were higher in breast than in liver. These current results were higher than those obtained by (Hussain et al., 2016) who declared that history of feeding on mycotoxins contaminated feed. Also, bad sanitary measures in abattoirs as contaminated water, air sources, contaminated tools, equipment, mishandling of carcasses on preparation after slaughtering beside improper evisceration. That in role led to higher bacterial count. In addition to bad chilling and bad storage conditions proliferate mould contamination so food spoilage occur that enhance mycotoxins production as aflatoxins (Darwish et al., 2016; Lacumin et al., 2009; Martín-Sánchez et al., 2011).

Due to the public health risk of aflatoxins residues and their presence in our food threating human health our results agreed with those reported by Bennett and Klich (2003) and Miliţă et al. (2010) who revealed that liver is the target organ for aflatoxins. In human aflatoxins residues are lethal due to intoxication, while in chronic accumulation aflatoxins poisoning lead to hepatocellular carcinoma.

The present results were in constant and supported with those achieved by Duarte et al.
(1997) who reported that liver and kidneys of poultry having aflatoxins must not be allowed to human consumption even poultry allowed to withdrawal time before slaughtering. The results in table (2) were in competence agreed with those obtained by Gregory et al. (1983), Richard et al. (1986) and Hammad et al. (2006) who found that by using HPLC the residual level of aflatoxins in turkey liver were higher than in meat. These present results were higher than those obtained by Hammad et al. (2006) and this may be due to history of feeding on mycotoxins contaminated feed.

In addition to bad chilling, mould contamination proliferate so food spoilage occur that enhance mycotoxin production as aflatoxins (Gracy, 1981; Kalcher et al., 2007). The present results were agreed with those reported by Giambrone et al. (1985), Leeson et al. (1995), Quist et al. (2000), Bintvihok (2001) and Diaz and Murcia (2011) who reported that turkeys are extremely sensitive to aflatoxins. Aflatoxicosis in turkeys pose a heavy economic loss. Contamination of turkey carcasses with AFB1 leads to a public health risk threating human being because AFB1 is an extremely potent carcinogenic effect (Hammad et al., 2006).

\section{REFERENCES}

Abd El Monem, M., Ragab, M., Maher, M.A., Ali, S.H.H., Salah, N., Hussien, H.M., Amro, F.H., 2015. Detection of aflatoxins in meat by modified HPLC method. Egypt. J. Chem. Environ. Health 1, 945-954.

Abo El-Yazeed, H., Hanafy, M.H., Soliman, R., Refai, M., 2015. Trials for Reducing Aflatoxin B1 Residues in Chicken Meat and Eggs using a Newly Developed Aflatoxin B1 Vaccine. International Journal of Research Studies in Biosciences (IJRSB) 3, 6-14.

Anklam, E., Stroka, J., Boenke, A., 2002. Acceptance of analytical methods for 
implementation of EU legislation with a focus on mycotoxins. Food Control, 13: 173183, 16th ed. Association Of Analytical Communities (AOAC)(1995):Method 990.33, Official methods of analysis.

Bennett, J.W., Klich, M., 2003. Mycotoxins. . Clin. Microbiol. Rev. 16, 497-516.

Bintvihok, A., 2001. Controlling aflatoxin danger to duck and duck meat. World Poultry Sci. J. 17, 18-20.

Dance, Z., Popa, M., Morar, M.V., Macri, A., Mihalca, I., Buda, I., 2003. A survey of the occurrence of fungi with mycotoxic potential in grain of transilvania, 25 Mycotoxin-workshop, Giessen. Rev. Med. Vet. 13.

Darwish, W.S., ELBayomi, R.M., AbdEL-oaty, A.M., Gad, T.M., 2016. Mould contamination and aflatoxin residues in frozen chicken meat cuts and giblets. Japanese Journal of Veterinary Research 46, 167-171.

Diaz, G.J., Murcia, H.W., 2011. "Biotransformation of aflatoxin B1 and its relationship with the differential toxicological response to aflatoxin in commercial poultry species." Aflatoxins Biochemistry and Molecular Biology. Ramon G. Guevara-Gonzalez (Ed).

Diekman, M.A., Green, M.L., 1992. Mycotoxins and eproduction in domestic live stock. Journal of Animal Science 70, 1615-1627.

Duarte, R.R., DE, E.C.O., Carvaalho, Rose, C.A.R., 1997. Aflatoxin in the liver of broilers with fatty liver, slaughtered commercially in Riode Janeiro state Brazil. Revista brasileira de cienica veterinaria 4 , 117-120.

Feldman, D., Ganon, J., Haffman, R., Simpson, J., 2003. The solution for data analysis and presentation graphics, 2nd ed. Abacus Lancripts, Inc., Berkeley, USA.

Giambrone, J.J., Diener, U.L., Davis, N.D., Panangala, V.S., Hoerr, F.J., 1985. Effects of aflatoxin on young turkeys and broiler chickens. Poult Sci. 64, .

Gracy, J.F., 1981. Thorntons meat hygiene, 7th ed. Bailliere Tindall, London.

Gregory, J.F., Goldstein, S.L., Edds, G.T., 1983. Metabolite distribution and rate of residue clearance in Turkeys fed a diet containing aflatoxin B1. Food and Chemical Toxicology 21, 463-467.

Hammad, A.M., GabAllah, H.M., Ragheb, R.R., 2006. Mycological and mycotoxicological evaluation of turkey carcasses marketed in Sharkia province. Vet. Med. J 54, 405-412.
Herzallah, S.M., 2013. Aflatoxin b1 residues in Eggs and flesh of laying hens Fed aflatoxin b1 contaminated diet. American Journal of Agricultural and Biological Sciences 8, 156161.

Hussain, Z., Rehman, H.U., Manzoor, S., Tahir, S., Mukhtar, M., 2016. Determination of liver and muscle aflatoxin $\mathrm{B} 1$ residues and select serum chemistry variables during chronic aflatoxicosis in broiler chickens. . Vet. Clin. Pathol, 45, 330-334.

IARC, 1993. nternationa Agency for Research on cancer 1987. IARC. Monographs on the evaluation of carcinogenic risk to human. Some naturally occurring substances, food item and constituents, Heterocyclic aromatic amines and mycotoxins, lyon, France

Kalantari, H., Zandmoqadam, H., Abdolahilorestani, S., 1999. Determination of aflatoxins B1 and M1 in liver by HPLC. Journal of Ahwaz University Agriculture 22.

Kalcher, T.C., Vrta, C., Pestev, S.E.K., Vengu, S.T., 2007. Validation of the procedure for the determination of aflatoxin B1 in animal liver using immunoaffinitycolumns and liquid chromatography with postcolumnderivatizationand fluorescence detection. Food Control 18, 333-337.

Lacumin, L., Chiesa, L., Boscolo, D., Manzano, M., Cantoni, C., Orlic, S., Comi, G., 2009. Moulds and ochratoxin A on surfaces of artisanal and industrial dry sausages. Food Microbiol 26, 65-70.

Leeson, S., Diaz, G.J., Summers, J.D., 1995. "Poultry metabolic disorders and mycotixns, University Books, Guelph, Ontario, Canada.

Martín-Sánchez, A.M., Chaves-López, C., Sendra, E., Sayas, E., Fenández-López, J., PérezÁlvarez, J.A., 2011. Lipolysis, proteolysisand sensory characteristics of a Spanishfermented dry-cured meat product (salchichón)with oregano essential oil used as surface moldinhibitor. Meat Sci. 89, 3544.

Miliţă, N.M., Mihăescu, G., Chifiriuc, C., 2010. Aflatoxins health risk factors. Bacteriol Virusol Parazitol Epidemiol 55, 19-24.

Quist, C.F., Bounous, D.I., Kilburn, J.V., Nettles, V.F., Wyatt, R.D., . 2000. The effect of dietary aflatoxin on wild turkey poults. J Wildl Dis 36, 436-443.

Resanović, R., 2000. Ispitivanje zaštitnog dejstva modifikovanog klinoptilolita na živinu izloženu deistvu aflatoksina. Doktorska disertacija, Fakultet veterinarske medicine Uni $\urcorner$ verzitet u Beogradu, Beograd. ( Sr). 
Richard, J.L., Stubblefield, R.D., Lyon, R.L., Peden, W.M., Thurston, J.R., Rimler, R.B., 1986. Distribution and clearance of aflatoxins B1 and M1 in turkeys fed diets containing 50 or $150 \mathrm{ppb}$ aflatoxin from naturally contaminated corn. Avian Dis 30, 788-793.

Saeed, A., Afzal , S., Hussien, M.W., Bokhari, S.Y.A., Shahzad, M.S., Qayyoum, A., Raza,
M.H., 2003. Effect of aflatoxin B1 on different body tissues of Gallus Domesticus. Journal of animal and veterinary Advances 2, 76-78.

Talebi, E., Khademi, M., Rastad, A., 2011. An Over Review on Effect of Aflatoxin in Animal Husbandry. Asian J. Exp. Biol. Sci. 2, 754-757. 